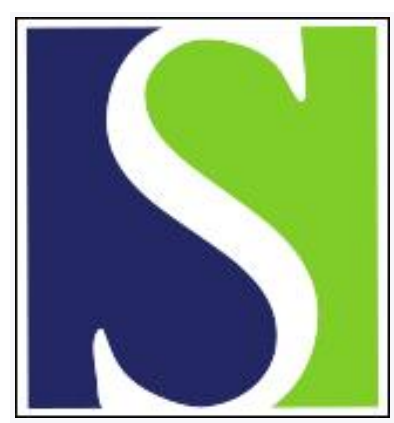

Scand J Work Environ Health 1984;10(4):225-228

https://doi.org/10.5271/sjweh.2340

Issue date: Aug 1984

Neuroendocrine effects of styrene on occupationally exposed workers.

by Mutti A, Vescovi PP, Falzoi M, Arfini G, Valenti G, Franchini I

This article in PubMed: www.ncbi.nlm.nih.gov/pubmed/6436966

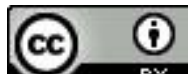




\title{
Neuroendocrine effects of styrene on occupationally exposed workers
}

\author{
by Antonio Mutti, MD, ${ }^{1}$ Pier P Vescovi, MD, ${ }^{2}$ Maurizio Falzoi, MD, ${ }^{1}$ Giuseppe Arfini, MD, ${ }^{1}$ \\ Giorgio Valenti, $M D{ }^{2}$ Innocente Franchini, $M D^{1}$
}

\begin{abstract}
MUTTI A, VESCOVI PP, FALZOI M, ARFINI G, VALENTI G. FRANCHINI I. Neuroendocrine effects of styrene on occupationally exposed workers. Scand J Work Environ Health 10 (1984) 225-228. The serum levels of prolactin (PRL), human growth hormone (HGH), thyroid-stimulating hormone (TSH), and the gonadotropins follicle-stimulating hormone (FSH) and luteinizing hormone (LH) were measured in 30 females exposed to about 130 (range 65-300) ppm of styrene in the air and in 30 agematched referents to show whether styrene exposure influences the dopaminergic tuberoinfundibular system (TIDA). The exposed subjects' serum levels of PRL were more than double the reference values and were significantly related to the urinary excretion of styrene metabolites, ie, to the sum of mandelic acid (MA) and phenylglyoxylic acid (PGA) in the "next-morning" urine spot sample. Such a relationship still proved to be statistically significant after the removal of the effects of age and duration of exposure with the method of partial correlation. The serum concentrations of HGH in the exposed workers were also higher than in the reference group. Though within the reference levels, the TSH values of the exposed subjects were significantly related to the urinary excretion of MA and PGA. These results are consistent with the dose-dependent depletion in tuberoinfundibular dopamine after experimental styrene exposure of rabbits.
\end{abstract}

Key terms: dopamine, gonadotropins, growth hormone, prolactin, thyroid-stimulating hormone, reinforced plastics.

By using electrophysiological techniques $(10,12,21$, 22) and neuropsychological methods $(3,4,8,9,13$, 19), several field and experimental studies have given evidence of styrene toxicity to the central nervous system. Exposure-effect and exposure-response relations have been found for visuomotor and visuoperceptive abilities, vigilance, and memory functions $(10,16,17)$.

The neurochemical and pathophysiological bases for styrene-induced central nervous dysfunction have not yet been fully elucidated. Some evidence is available of biochemical changes leading to abnormal brain protein metabolism, after repeated exposures of rats to styrene vapors (20). A possible interference of styrene and/or its metabolites with the concentration and activity of brain catecholamines has also been suggested $(1,11,15)$. These different mechanisms might coexist and account for some mild chronic abnormalities, eg, abnormal electroencephalographic findings, and the acute behavioral effects of styrene exposure on humans.

The present study was aimed at evaluating the possible interference of styrene or its metabolites with

\footnotetext{
1 Institute of Internal Medicine and Nephrology, University of Parma, Parma, Italy.

2 Institute of Internal Medicine and Therapeutics, University of Parma, Parma, Italy.
}

Reprint requests to: Dr A Mutti, Istituto di Clinica Medica e Nefrologia, Universita' degli Studi, Via Gramsci 14, I-43100 Parma, Italy. the activity of the tuberoinfundibular dopaminergic system (TIDA) in humans. Such an effect was indirectly investigated with measurements of some neuroendocrine parameters, namely, serum prolactin (PRL), human growth hormone (HGH), thyroidstimulating hormone (TSH), and gonadotropins [follicle-stimulating hormone (FSH) and luteinizing hormone (LH)].

\section{Subjects and methods}

\section{Subjects}

The exposed group was composed of 30 female workers employed in two factories manufacturing glass-fiber reinforced boats and silos. Their mean age was 28.6 (SD 12.7) years, and their exposure time to styrene vapors averaged 6.2 (SD 4.6 ) years. The reference group was composed of 30 age-matched females selected from a pool of factory workers living in the same area as the styrene-exposed subjects and not exposed to industrial chemicals. Their mean age was 29.2 (SD 10.5) years. Both the exposed and the reference subjects were healthy workers, with no history or clinical signs of endocrine and neurological diseases. Information about the menstrual cycle was collected with a questionnaire. Only those subjects in the proliferative phase (between the 5th and the 15th day of the cycle) were admitted to the study. None of them had been receiving psychotropic drugs. 
Table 1. Neuroendocrine effects of styrene exposure. $(\mathrm{PRL}=$ serum prolactin, $\mathrm{TSH}=$ thyroid-stimulating hormone, $\mathrm{HGH}=$ human growth hormone, FSH = follicle-stimulating hormone, $\mathrm{LH}=$ luteinizing hormone)

\begin{tabular}{|c|c|c|c|c|c|}
\hline Group & $\begin{array}{c}\text { PRL } \\
\text { (pmol/l) }\end{array}$ & $\begin{array}{c}\text { TSH } \\
(\mathrm{mIU} / \mathrm{l})\end{array}$ & $\underset{(\mathrm{pmol} / \mathrm{l})}{\mathrm{HGH}}$ & $\begin{array}{c}\mathrm{FSH} \\
(\mathrm{mlU} / \mathrm{l})\end{array}$ & $\underset{(\mathrm{mIU} / \mathrm{l})}{\mathrm{LH}}$ \\
\hline \multicolumn{6}{|l|}{ Exposed } \\
\hline $\begin{array}{l}\text { Mean } \\
\text { SD }\end{array}$ & $\begin{array}{l}633^{* \star} \\
372\end{array}$ & $\begin{array}{l}2.3 \\
1.3\end{array}$ & . & : & \\
\hline $\begin{array}{l}\text { Median } \\
\text { Range }\end{array}$ & . & : & $\begin{array}{c}520^{*} \\
65-1,422\end{array}$ & $\begin{array}{c}10.1 \\
3.6-118.8\end{array}$ & $\begin{array}{c}13.4 \\
9.2-107.7\end{array}$ \\
\hline \multicolumn{6}{|l|}{ Reference } \\
\hline $\begin{array}{l}\text { Mean } \\
\text { SD }\end{array}$ & $\begin{array}{l}313 \\
175\end{array}$ & $\begin{array}{l}2.7 \\
1.8\end{array}$ & . & : & . \\
\hline $\begin{array}{l}\text { Median } \\
\text { Range }\end{array}$ & : & : & $\begin{array}{l}329 \\
67-1.198\end{array}$ & $\begin{array}{c}8.8 \\
-187\end{array}$ & 11.7 \\
\hline
\end{tabular}

* $p<0.05$ (Mann-Whitney U-test), ** $p<0.001$ (Student's t-test, two-tailed).

Table 2. Simple and partial correlation coefficients between styrene exposure and those neuroendocrine varlables normally distributed among the exposed group. ( $\mathrm{PRL}=$ serum prolactin, $\mathrm{TSH}=$ thyroid-stimulating hormone, $\mathrm{MA}=$ mandelic acid, $P G A=$ phenylglyoxylic acid)

\begin{tabular}{|c|c|c|}
\hline & PRL & TSH \\
\hline $\begin{array}{l}\text { Zero order } \\
\text { Styrene metabolites } \\
\text { (MA + PGA) } \\
\text { Exposure time (years) } \\
\text { Age (years) }\end{array}$ & $\begin{array}{l}0.573^{* * *} \\
-0.407^{*} \\
-0.450^{* *}\end{array}$ & $\begin{aligned} & 0.321^{*} \\
- & 0.122 \\
- & 0.197\end{aligned}$ \\
\hline $\begin{array}{l}\text { Control for exposure time } \\
\text { Styrene metabolites } \\
\text { (MA + PGA) }\end{array}$ & $0.575^{* * *}$ & $0.310^{*}$ \\
\hline $\begin{array}{l}\text { Control for age (years) } \\
\text { Styrene metabolites } \\
\text { (MA+ PGA) } \\
\text { Exposure time (years) }\end{array}$ & $\begin{array}{l}0.617^{* * *} \\
-0.158\end{array}$ & $\begin{array}{l}0.317^{*} \\
0.013\end{array}$ \\
\hline $\begin{array}{l}\text { Control for age (years) and } \\
\text { styrene metabolites (MA + PGA) } \\
\text { Exposure time (years) }\end{array}$ & -0.100 & 0.058 \\
\hline $\begin{array}{l}\text { Control for age (years) and } \\
\text { exposure time (years) } \\
\text { Styrene metabolites } \\
\text { (MA + PGA) }\end{array}$ & $0.609^{* * *}$ & $0.322^{*}$ \\
\hline
\end{tabular}

\section{Exposure}

The urinary excretions of mandelic acid (MA) and phenylglyoxylic acid (PGA) in the "next-morning" urine spot samples were used as biological indicators of internal dose. Exposure intensity was rather high, as measured by the sum of MA and PGA, the mean value being 580 (SD 290) $\mathrm{mmol} / \mathrm{mol}$ of creatinine. On the basis of the relationship between environmental and biological exposure test measurements, such values correspond to an 8-h time-weighted concentration of about 130 (range 65-300) ppm of styrene in the air (6).

\section{Methods}

The urine samples were collected immediately before the venipuncture for blood sampling. Urine, adjusted to $\mathrm{pH} 2$ with $1 \mathrm{~mol}$ of hydrochloric acid, was stored at $-20^{\circ} \mathrm{C}$ up to the time of analysis, which was carried out in the following $2 \mathrm{~d}$ by high-performance liquid chromatography according to the method described elsewhere (7). The styrene metabolite levels were then adjusted for creatinine, which was measured by the Jaffe reaction with a Technicon Auto Analyzer. Tenmilliliter venous blood samples were taken while the subjects were seated before they started work in the morning (from 0800 to 0900). Serum was centrifuged as soon as possible and stored at $-20^{\circ} \mathrm{C}$ up to the time of analysis, which was performed in triplicate within a month. Commercially available kits (Biodata, Milan) were used for the radioimmunoassay of PRL, HGH, TSH, FSH, and LH.

Statistical analysis was carried out with the SPSS programs (18). After the testing for a normal distribution of both the referents' and the exposed subjects' hormone levels with the use of the nonparametric Kolmogorov-Smirnov test, any significant differences between the two groups were assessed by the Student's t-test (for PRL \& TSH) or the MannWhitney U-test (for HGH, FSH, \& LH). Pearson's correlation coefficients were used to identify any relationship between independent variables and serum hormone levels.

The partial correlation method was used to remove the effects of age and duration of exposure from the dose-effect relationships.

\section{Results}

Table 1 shows the comparison between the exposed subjects and the referents. The serum levels of PRL and $\mathrm{HGH}$ were about double the reference values, the difference being statistically significant. No difference could be detected for TSH and the gonadotropins, although the latter were slightly higher in the exposed subjects than in the referents.

Table 2 summarizes Pearson's correlation coefficients between the independent variables and those neuroendocrine variables normally distributed among the exposed group. The partial correlation coefficients are also reported after control for the possible effects of any interrelationship between the independent variables. The serum levels of PRL and TSH were significantly related to the urinary excretion of styrene metabolites, ie, to the sum of MA and 


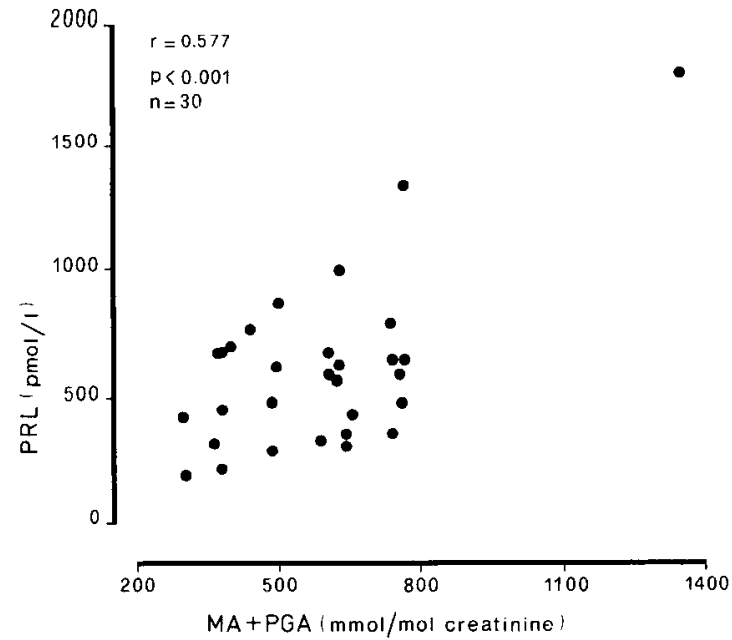

Figure 1. Relationship between the urinary excretion of mandelic acid (MA) and phenylglyoxylic acid (PGA) in the "nextmorning" spot sample and the basal serum level of prolactin (PRL).

PGA in the "next-morning" urine spot sample. Both age and exposure time were negatively related to serum PRL. After control for age and exposure time, the PRL and TSH levels still proved to be related to the intensity of styrene exposure. After control for age and exposure intensity, the negative relationship between duration of exposure and serum PRL was not statistically significant.

Figure 1 shows the correlation between serum PRL and the sum of MA and PGA in the "next-morning" urine sample. Though not statistically different as compared to the reference values, the TSH serum levels also correlated with the urinary excretion of styrene metabolites (figure 2).

\section{Discussion}

The role of TIDA neurons in the control of pituitary hormone secretions has been stressed by several studies dealing with the diagnostic or therapeutic use of dopamine agonist and antagonist drugs in subjects with hypophyseal adenoma. It is well established that, in a number of neurotransmitters and neuromodulators, the dopaminergic pathways have an inhibitory function on pituitary secretion. PRL secretion is directly controlled by the activity of TIDA neurons, whereas the more complex modulation of $\mathrm{HGH}$, $\mathrm{TSH}$, and $\mathrm{LH}$ is indirectly performed through the inhibition of hypophysiotropic neurons secreting somatostatin (SRIF), thyrotropin-releasing hormone (TRH), and LH-releasing hormone (LH-RH) (14).

The results of the present study strongly support the hypothesis of an interference of styrene exposure with TIDA activity in humans. To our knowledge, this is the first paper dealing with the neuroendocrine effects of styrene exposure. Thus no comparison is

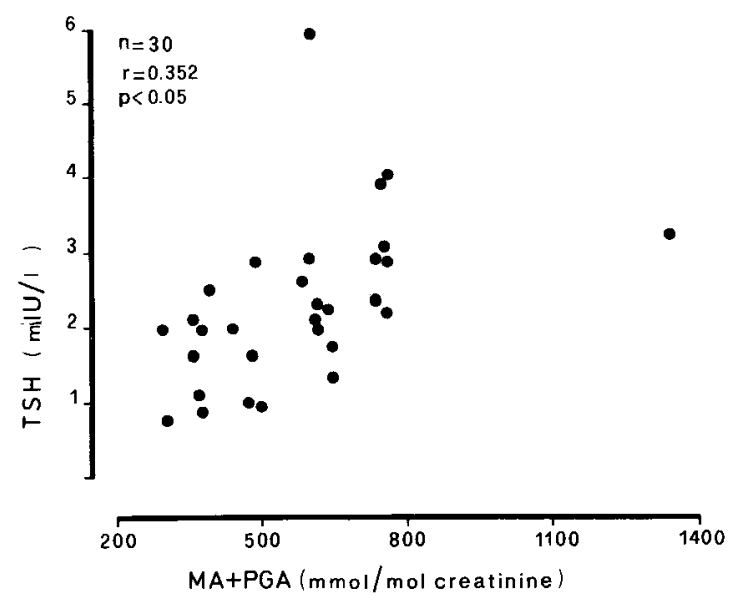

Figure 2. Relationship between the urinary excretion of mandelic acid (MA) and phenylglyoxylic acid (PGA) in the "nextmorning" spot sample and the basal serum level of thyroidstimulating hormone (TSH).

possible with the available findings in the literature. A previous experimental study had given evidence of a dose-dependent depletion in striatal and tuberoinfundibular dopamine after the acute styrene exposure of rabbits (15). A selective inhibition of brain dopamine receptors after repeated oral administration of styrene to rats has also been reported (1). Though the pathophysiological bases of such effects are not yet fully understood, the available experimental data are consistent with the results we have obtained with humans.

We speculate that a styrene metabolite, possibly PGA, might be aminated to the alpha-amino acid phenylglycine. The latter would compete with dopamine for vescicular storage capacity, as do some biogenic amines, namely, phenylethylamines (5).

Serum PRL is the most sensitive indicator of impaired TIDA activity. Moreover, it is directly controlled by dopaminergic neurons, which are further stimulated by increased serum PRL through a feedback mechanism. By contrast, the indirect inhibitory role of dopamine on TSH release, which is mediated by the control of TRH secretion, would make this hormonal response less sensitive to TIDA activity. The modulatory role of dopamine upon the pituitary secretion of $\mathrm{HGH}$ and gonadotropins requires an even more complex interaction with other neurotransmitters, neuromodulators, or hormones. Moreover, the variability of $\mathrm{HGH}$ and gonadotropins may be explained in part by the fact that only one blood sample was drawn. This occurrence might affect the reliability of the $\mathrm{HGH}$ and $\mathrm{LH}$ values, though both the exposed and reference subjects were examined under the same conditions.

The styrene-induced neuroendocrine effects are mostly due to acute exposure, the hormone levels not being influenced by the duration of exposure, after 
control for age and exposure intensity with the partial correlation method.

Owing to the lack of specificity, the neuroendocrine parameters cannot be recommended for the biological monitoring of occupational exposure to styrene. Moreover, such effects on hypophyseal secretion were observed at exposure levels much higher than $50 \mathrm{ppm}$, ie, levels higher than the current threshold limit value recommended by the American Conference of Governmental Industrial Hygienists (2).

\section{Acknowledgments}

The skillful technical assistance of Dr L Bacchini Generali is gratefully acknowledged. This study was supported by the Consiglio Nazionale delle Ricerche, Progetto Finalizzato Medicina Preventiva e Riabilitativa, SP.3: Malattie del Sistema Nervoso, contr. 82.02175.56, and by the Department of Social Security, Region Emilia-Romagna.

\section{References}

1. Agrawal AK, Srivastava SP, Seth PK. Effect of styrene on dopamine receptors. Bull Environ Contam Toxicol 29 (1982) 400-403.

2. American Conference of Governmental Industrial Hygienists. Documentation of the threshold limit values. Fourth edition. Cincinnati, OH 1980, pp 373374.

3. Cherry N, Rodgers B, Venables H, Waldron HA, Wells GG. Acute behavioral effects of styrene exposure: A further analysis. $\mathrm{Br} \mathrm{J}$ Ind Med 38 (1981) $346-350$

4. Cherry N, Waldron HA, Wells GG, Wilkinson RT, Wilson HK, Jones S. An investigation of the acute behavioural effects of styrene on factory workers. $\mathrm{Br} \mathbf{J}$ Ind Med 37 (1980) 234-240.

5. Coyle JT, Snyder SH. Catecholamines. In: Siegel GJ, Albers RW, Agranoff BW, ed. Basic neurochemistry. Little, Brown \& Co, Boston, MA 1980, pp 205-217.

6. Franchini I, Angiolini A, Arcari C, Falzoi M, Ferrari C, Ferri F, Lucertini S, Mutti A. Mandelic acid and phenylglyoxylic acid excretion in workers exposed to styrene under model conditions. In: Hayes AW, Schnell RC, Miya TS, ed. Developments in the science and practice of toxicology: Proceedings of the Third International Congress on Toxicology, San Diego, CA Aug 28-Sep 3, 1983. Elsevier Science Publishers, Amsterdam, New York, Oxford 1983, pp 567-570.

7. Gaetani E, Laureri CF, Vitto M, Falzoi M, Mutti A. Determinazione quantitativa nelle urine dei metaboliti dello stirene, gli acidi mandelico e fenilgliossilico. Med Lav 73 (1982) 408-411.

8. Gamberale F, Lisper HO, Olson BA. The effect of styrene vapour on the reaction times of workers in the plastic boat industry. In: Horvath $\mathrm{M}$, ed. Adverse effects of the environmental chemicals and psychotropic drugs. Volume 2. Elsevier, Amsterdam 1979, pp 135148.

9. Götell P, Axelson O, Lindelöf B. Field studies ort human styrene exposure. Work Environ Health 9 (1972) $76-83$.

10. Härkönen $\mathbf{H}$, Lindström $K$, Seppäläinen AM, Asp $S$, Hernberg S. Exposure-response relationship between stryene exposure and central nervous functions. Scand J Work Environ Health 4 (1978) 53-59.

11. Husain R, Srivastava SP, Musthaq M, Seth PK. Effects of styrene on levels of serotonin, noradrenaline, dopamine and activity of acetyl cholinesterase and monoamine oxidase in rat brain. Toxicol Lett 7 (1980) $47-50$.

12. Klimkova-Deutschova E. Neurologische befunde in der plastikindustrie styrol arbeitern. Int Arch Gewerbepath Gewerbehyg 18 (1962) 35-50.

13. Lindström K, Härkőnen $H$, Hernberg S. Disturbances in psychological functions of workers occupationally exposed to styrene. Scand J Work Environ Health 2 (1976) 129-139.

14. Müller EE, ed. Neuroactive drugs in endocrinology. Elsevier North-Holland, Amsterdam 1980.

15. Mutti A, Falzoi M, Romanelli A, Franchini I. Regional alterations of brain catecholamines by styrene exposure in rabbits. Arch Toxicol (in press).

16. Mutti A, Mazzucchi A, Frigeri G, Falzoi M, Arfini G, Franchini I. Neuropsychological investigation on styrene exposed workers. In: Gilioli $R$, Cassitto $M G$, Foa' V, ed. Neurobehavioural methods in occupational health, Pergamon Press, Oxford \& New York 1983, pp 271-281.

17. Mutti A, Mazzucchi A, Rustichelli P, Frigeri G, Arfini G, Franchini I. Exposure-effect and exposure-response relationships between occupational exposure to styrene and neuropsychological functions. Am J Ind Med 5 (1984) 275-284.

18. Nie NH, Hull CH, Jenkins JG, Steinbrenner K, Bent DH. SPSS: Statistical package for the social sciences. McGraw-Hill, New York 1975.

19. Oltramare M, Desbaumes E, Imhoff C, Michiels W. Toxicologie du styrene monomere: Recherches experimentales et cliniques chez l'homme. Editions Medicine et Hygiene, Geneve 1974.

20. Savolainen $H$, Vainio $H$. Effects of chronic styrene inhalation on rat brain protein metabolism. Acta Neuropathol 40 (1977) 237-241.

21. Seppäläinen AM, Härkönen $\mathbf{H}$. Neurophysiological findings among workers occupationally exposed to styrene. Scand J Work Environ Health 2 (1976) 140146.

22. Stewart RD, Dodd HC, Baretta ED, Schaffer AW. Human exposure to styrene vapour. Arch Environ Health 16 (1968) 656-662.

Received for publication: 7 May 1984 